\title{
8
}

\section{Policymaking, party executives and parliamentary policy actors}

Marija Taflaga

Public policy and policymaking discussions often de-emphasise the role of 'capital P' politics, which scholars typically think of as occurring within political parties or on the floor of parliaments. There is a good reason for this - much of the traditional focus on policymaking examines the interaction between the executive and the bureaucracy. Recently, scholars have acknowledged the institutionalised influence of third-party policy communities that orbit executives, such as interest groups, quangos, other tiers of government and non-executive actors within parliament itself. Nevertheless, given the executive's critical place in decision-making and within chains of delegation and accountability, this core relationship remains the point of tension between two sets of actors: ministers as principals and decision-makers, and bureaucrats as their agents, tasked with design, implementation and evaluation. Politics is always there, as wildcard, trump card, perhaps a spanner in the works or worse still a wrecking ball. But the perception appears to be that politics - by which I mean the interplay between the executive and parliament through party conflict - gets in the way of business as usual, of good practice, of the real work of policymakers. 
Over decades, policymaking has been conceptualised in multiple ways: as a cycle (Lasswell 1956; Jones 1970; Althaus, Bridgman and Davis 2007); or a garbage can (Cohen, March and Olsen 1972); as multiple streams (Kingdon 1984); as multi-levelled (Rhodes 1997; Richards and Smith 2004); or as the result of policy networks (Rhodes 1997, 2006) distributed largely outside the reach of government. Given that much of the interest in public policy relates to the overall success of implementation and evaluation of outcomes, it makes sense that the political dimensions, such as they are, should be viewed through a public policy-focused lens. Yet, discounting the political dimension leaves the question about how public policy and 'capital P' politics interrelate underdeveloped, and the answer not quite complete, for citizens seeking to understand how power is wielded.

In Westminster parliamentary democracies like Australia, executives do not arrive from nowhere. They are party members, elected to parliament under party labels. Governments are really party governments (Lucy 1993; Kopecký et al. 2012; Mair 2007), just as the official opposition is party opposition. It's important not to forget the reality that it is political parties that inhabit both legislative and executive roles, animating these institutions and interpreting their norms and conventions. It remains the case that political parties overwhelmingly exercise, and sometimes even reshape, the powers of the executive and legislature.

Since the 1970s, ministers have demanded increased 'responsiveness' from the public service, as a strategy to reassert the role of elected representatives over the work of governments. Over this same time period, political scientists have discussed the growing professionalisation of the political elite (King 1981; Pakulski and Tranter 2015; Cairney 2007; Miragliotta and Errington 2012; Best and Cotta 2000). Today, there is growing evidence that ministerial selection is linked to a previous career in the 'persuasion industries' - such as in a political office, think tank or advocacy organisation (Allen 2013, 2014; Cowley 2012; Goplerud 2015). Further, political staff have become an institutionalised third pillar (Maley 2015) of executive governance (Craft 2016, 2015; Connaughton 2010, 2015; Wilson 2015). The pathway into executive government appears to be becoming more networked and politicised. The opportunity parliament presents as a platform for elected elites has important policy implications. 
One of the calling cards of John Wanna's work is to readily acknowledge not only the importance of party and parliamentary politics, but also to engage with the way in which it complicates relationships. Wanna's work fits into a tradition that straddles public policy and a more traditional political science view of how government works. This is most evident in Rhodes and Wanna's critique of public value, where they argue that politics is portrayed as a problem rather than integral to advisory systems (Rhodes and Wanna 2007). This broader view, conceptualising policymaking and government management systems as part of a wider policy advisory system (Craft and Halligan 2017) that is shaped by tradition, myths and 'capital P' politics (Rhodes, Wanna and Weller 2009) offers an important touchstone for our understanding of how decisions are made - and by whom - over time. In this chapter, I argue in favour of a greater recognition of the place of party and parliamentary politics in broader discussions of public policy and explain why it matters for policy researchers.

\section{Institutional design and policymaking}

The rise of disciplined two-party systems within Westminster democracies has seen a long-running discussion about the decline in the importance of parliament as the preeminent site for policy debate (Uhr and Wanna 2000). Parliaments are dominated by the executive, akin to 'elected dictatorships', able to ram through their policy agendas with minimal opposition from the legislature. This trend is amplified by the increasing expectations on government and the assumption that its work is becoming more complex. While this remains a broad generalisation across Westminster, the reflexive referral to parliament - a technical and (often) perfunctory step - in the policy development and legitimation process is overly simplistic. The argument is often used as a way to differentiate between different political systems and/or as a ready justification to ignore the political dimensions of policymaking in order to focus on bureaucratic or third-sector actors (e.g. see Cairney 2012; or from an Australian perspective Althaus, Bridgman and Davis 2007). Indeed, 40 years ago Richardson and Jordan (1979) went as far as to argue that polities such as the UK are 'post-parliamentary' and that policy formulation is the result of negotiation between government and advocacy groups. 
Yet, as Uhr and Wanna (2000) have argued, parliament is now a 'theatre of action', where its role has become more diffuse and is, arguably, far broader than originally conceptualised by Bagehot (1963), Dicey (1982) or Jennings (1966). Further, recent work on policy agendas (Dowding and Martin 2017) demonstrates that there remains a close link between what executives say they want to do, and what they attempt to legislate in parliament for policy domains such as economics, defence, immigration and workplace relations. They also found differences between the executives' policy focus compared with the opposition and the media. These differences highlight both the agenda setting and accountability functions of parliament. Ultimately, major policy initiatives must make it to parliament for legitimation and parliament remains an important site to pressure governments for change and to reform existing policy structures.

Handwaving over parliament as executive-dominated and therefore tangential to policymaking ignores important political system differences in institutional design and their impact on policy outcomes. This is perhaps even more important as the scope of parliament's remit has become broader, and the notion of parliament's boundaries more porous. Indeed, deliberation appears to have spilled over beyond parliament into the media (Uhr and Wanna 2000), creating an effective 'third chamber' (Taflaga 2016). Rhodes, Wanna and Weller (2009) have noted that over the twentieth century, internal party deliberations have become more robust as a larger proportion of parliamentary deliberations have become 'rehearsed theatre'. This reflects the long-term trend over the twentieth century where the relative balance of deliberation within parliament is shifting between public and private domains - from the parliamentary chamber to debates within party rooms. However, this picture is becoming somewhat more complex in the twenty-first century, as parliament finds new ways to reassert itself and political parties' internal machinery is increasingly sidelined by party elites (Gauja 2013).

In Australia, the Senate is a powerful upper chamber - one of the most powerful in the world (Kaiser 2008). As Ganghof, Eppner and Pörschke (2018) argue, the reality that both the House and Senate are equally legitimate with near-equal powers, but that confidence in the government need only be secured in the Lower House, has allowed actors within both chambers to pursue different normative goals. That is, actors in the House are focused on asserting and maintaining the chamber's confidence in the government. But in the Senate, where confidence in the government is not required, this chamber is free to pursue tasks aimed at increasing 
deliberation and accountability. Reflecting these theoretical observations, research by Halligan, Miller and Power (2007) documents the growing role of the parliamentary committee system, particularly in the Senate. Halligan and colleagues note a resurgence of parliamentary institutions' capacity to reach out to the public when discussing policy proposals or evaluating outcomes. They have also documented the way committee processes have opened up policymaking opportunities for backbench MPs to redefine policy problems and solutions, particularly in domains where agendas are new and policy stances are undergoing refinement and clarification.

Indeed, the emergence of a modern committee system from the $1970 \mathrm{~s}$ onwards, in multiple Westminster jurisdictions, has also reasserted the policymaking role of Westminster parliaments. In the UK, reforms to parliamentary debate in the Commons, reforms to the House of Lords and changes to the committee system have increased the potential for parliamentary actors to influence outcomes, though most argue that reforms have not gone far enough (Bates, Goodwin and McKay 2017; Goodwin and Bates 2016). Recent evidence suggests that committee work is increasingly seen as a policy training ground and as a pathway into ministerial office (Goodwin, Bates and McKay 2018; Maley 2018). Further, committees provide meaningful opportunities for parliamentary actors, particularly oppositions, to influence policy outcomes. For actors locked out of established policy networks, committees are alternative sites to 'venue hop', in the hope of winning a receptive audience.

From a top-down perspective, policymaking is largely seen as the preserve of governments. In Westminster contexts, this tendency is exaggerated by tension between responsible government, which emphasises the role of executives, and parliamentary government, which encompasses more actors, but where responsible government's legitimacy resides (Halligan 2008). Further, Westminster executive-bureaucratic relationships are explicitly hierarchical (Wanna and Weller 2003). In this light, policymaking functions as a means of hypothesis-testing and deliberate choice-making on the part of political actors, most commonly conceptualised in the literature as ministers or executive actors. Policy formulation is facilitated by a set of structured processes undertaken by the public service, political party infrastructure or outside third parties such as think tanks, interest groups or organised policy communities. Importantly, actors' choices are made consciously in the dynamic context of government and the political dimensions of policy decisions (Althaus, Bridgman and Davis 2007, 6-7). 
In this sense, for political actors, policy functions as a tool to reconcile philosophical and ideological aims with real world realities. It could be the need for a solution to a public scandal, to satisfy an important interest group or to simply appear to be doing something. These political motivations can coexist with policy choices that may be the product of long-running deliberations to deliver outcomes to citizens. Ultimately, which policies are pursued reflect political actors' priorities - indeed, as Wanna has argued, political parties can even 'prevent wider policy debate by internalising disputes or options' (Wanna 1993, 52). Put another way, policymaking sorts out political problems, and policy is ultimately a means to an end.

However, ministers, prime ministers, executives and governments are not the only 'capital P' political actors with important influence on policy outcomes. For parliamentary actors (Prosser and Denniss 2015), and particularly the official opposition (Haddon 2012; Prasser 2010; Taflaga 2016), parliament is a key venue to influence policy debate either directly via the chamber floor, or more commonly, indirectly through the media. Parliamentary actors are able to use their resources for agenda setting and public education opportunities.

For the official opposition, their role as an alternative government is important in terms of agenda setting, policy development and legislating and evaluating outcomes. As Brendan McCaffrie (2012) has argued, a portion of government leaders' success can be attributed to the actions of their opposition, whether through ineptitude, timely support of a discrete policy or a long-term reform agenda. The last leads to reform consolidation - that is, accepting and building on the reforms of previous governments. This is because oppositions are seeking to replace the government, but are not by default always in permanent opposition to the government's actions. Indeed, oppositions may seek, or be invited, to contribute to the development of government policy (Norton 2008, 246). The opposition's capacity to influence outcomes is not necessarily dependent on their size, but is more to do with their successful exploitation of opportunities that parliamentary political systems offer (Kaiser 2008, 35). Given that successful governments regularly appropriate policy ideas from their opponents and adopt them with modifications, failure to consider the role of policymaking by nongovernment political actors understates the role of the political dimension in which actors that design, advocate and implement policy operate. 
Oppositions have gradually institutionalised their role since the nineteenth century. First as an institution of the parliament and more recently as an institutionalised alternative government via the shadow cabinet system (Punnett 1973; Bateman 2008). Over time, oppositions have received more resources to undertake this work, though their resource envelope remains modest compared with that of governments. Ultimately, opposition is the principal apprenticeship most ministers receive and one that they value (Tiernan and Weller 2010). Oppositions have been the principal beneficiaries of an increase in parliamentary scrutiny infrastructure, such as the modernisation of the Australian Senate committee system in 1970 and the Wright reforms in the UK. This is in addition to other parliamentary infrastructure to support policymaking such as the parliamentary budget office (which was first implemented in Canada). Despite parliament's overall decline in status, parliamentary actors actually have more resources to challenge the claims of executives and to make meaningful contributions to policy debates than at any time in the past. Further, the incentive structure for one unified and single message is increasingly under challenge by the rise of social media and the desire for authenticity in political leaders. It is not surprising then that, slowly, political institutions are adapting to create more space for political actors to have a say and influence policy outcomes.

But there are doubts as to how genuine oppositions are in their policymaking efforts. Uhr $(2009,74)$ has argued that over time oppositions have chosen to invest principally in election campaign planning rather than alternative policy platforms. Indeed, a Liberal political adviser, Scott Prasser (2010, 154-58), has argued that perhaps we expect too much from oppositions, who are ill-equipped to adequately develop policy and meet interest groups' and voter's expectations. In the mid-1990s, Wanna himself was pessimistic about the policymaking capacity of parties generally, in part driven by a lack of policy development practice in opposition (Wanna 1993, 48-49). Others disagree; for instance, Catherine Haddon argued forcefully that policymaking was a key exercise for political parties in opposition. Through the policymaking process, parties interpret and renew their principles (Haddon 2012, 4). They also develop contacts with the policy sectors that they can draw upon on in government (Riddell and Haddon 2009, 16; Tiernan and Weller 2010), and opposition policymaking represents an alternative option for those advocacy sector actors seeking to influence policy outcomes. 
Recent political experience suggests that interest by 'capital P' political actors in policymaking is likely cyclical - reflecting political circumstances and the skill sets of political leaders. As Australia's 'climate wars' made clear, 'blood and guts' politics still shapes many important policy outcomes, even as government's capacity to control outcomes has receded. Indeed, recent Australian experience has underlined the critical role both parliamentary actors and oppositions can play in derailing policy proposals that have undergone careful consultation, design, development and coordination. If policy measures, especially new initiatives, cannot consolidate parliamentary support, no amount of careful design and consultation can compensate.

\section{Actors and policymaking: The de-separation of political careers}

'Capital P' political actors are often decisive actors in the policymaking process. Typically, in Westminster systems, elected political actors are key decision-makers, veto players or actors with a greater capacity to increase the salience of issues than most others in a crowded policymaking field. As political scientists are increasingly uncovering, the career paths of elected elites have changed in profound ways in parallel to major changes in the policy advisory system.

Just as the consolidation of the party system changed the balance of parliamentary institutions, it has also changed the nature of who gets elected. Political parties were, and remain significant - but not the only gatekeepers between the public and government. As party organisations have evolved over time, their roles as democratic linkages (Dalton, Farrell and McAllister 2011) have become weaker over time and parties have begun to act more like cartels (Katz and Mair 2009), political scientists have observed that elected elites are drawn from a narrower class (Best and Cotta 2000) with a narrower skill base gained from working within 'instrumental' occupations that orbit the world of the political offices (Cairney 2007). The implications of this are not trivial - there are distinct changes in the way decision-making occurs within parties (Gauja 2013). This trend is exacerbated further as parties become more personalised and elections more focused on party leaders than party brands, which are likely to be less complex and focused on policy (Karvonen 2010). 
Career structures are also having a material impact on who is successful in becoming a member of the executive, in charge of making or vetoing key decisions (Dowding and Dumont 2015).

Another important aspect of the change in the career structure of elected elites in Westminster systems is the rise of political advisers. In part this relates to advisers' specific role in the policymaking process (Maley 2015; Craft 2015), acting as gatekeepers, brokers, generators of ideas and, most concerningly, as proxies for ministers. While there have undoubtedly been some positive outcomes, there are also well-documented concerns about their impact on the policy advisory system and the traditions of Westminster's professional and nonpartisan civil service (Peters and Pierre 2004). These are exemplified by the poor consequences of policy decisions taken by actors who are increasingly driven by short-term incentives and the decoupling of policy design from policy implementation (King and Crewe 2014).

Another aspect is the fact that political advising is increasingly a pathway to elected political office. As noted, the expansion of political offices and the broadening of the policy advisory system beyond the public service into the world of interest groups, think tanks and lobbyists has led to a proliferation of 'instrumental careers'. While it remains unclear what, if any, specific links exist between interest groups and the world of elected politics, there is growing evidence of the importance of political advising in elected careers. Evidence from the UK highlights how a career in staffing increases the likelihood of being selected as a candidate, elected to parliament and appointed to the executive (Goplerud 2015). Similar trends are being uncovered in Australia (Miragliotta and Errington 2012; Taflaga and Kerby 2020), though there are distinct differences in patterns in recruitment and the structure of career paths between men and women, for example.

As I have argued elsewhere with Keith Dowding (Dowding and Taflaga 2020), Westminster systems appear to have undergone a de-separation of careers at the top of government. That is, there were once two distinct career paths. On the one hand, a political path that had higher risks and, on the other, a professional path that existed to consider longterm consequences and restrain the worst excesses of popularly elected executives. Now these career paths are increasingly blurred, as increasing numbers of people move back and forth between partisan and nonpartisan roles (Maley 2017). The effect over decades has been to shift the balance 
of decisive decision-making power towards more amateur and partisanminded actors - or actors we would think of as 'capital P' political actors like elected elites and political advisers, which has a deleterious impact on the quality of policy formulation. While governments might be struggling to retain control as government becomes large, more diffuse and/or more complex, the need to look like they are in control is ever-pressing, as policy debate has increasingly become about 'political management'. This has led to what Patrick Diamond (2019) argues is government by permanent campaign. John Wanna's $(1993,49,53)$ own assessment in the mid-1990s was perhaps even more pessimistic, where parties were seen to 'preen' before the media to burnish their alternative government credentials and were made up of 'careerist politicians intent on surviving above doing anything else'.

Taken together, perhaps it is not surprising that the changing nature of political careers has moved in parallel to changes in policy advisory systems, with a greater emphasis on managerialism by bureaucrats (O’Faircheallaigh, Wanna and Weller 1999). Perhaps what is understated is that these processes are likely intertwined, with changes on one side of the political-professional divide impacting and shaping decisions and changes on the other.

\section{Conclusion}

Political policy actors outside of the executive, and those within the executive but who are not ministers, can and do assert their right and insert themselves into the policy development, legitimation and, in a more limited way, evaluation. Or as Rod Rhodes and John Wanna $(2009,168)$ have put it: "large "P" politics frames the decision structures for small "p" politics', within the world of policymakers. Over recent decades, political institutions have adapted to grant previously marginalised political actors more scope to influence policy debate. Under some conditions, political actors' influence can have disproportionate impact. At the same time that policy advisory systems have expanded, political career structures have also changed. It is likely that changes occurring on the 'capital P' politics side are impacting and interacting with processes underway within public policy institutions and systems. Public policy scholars obviously know that politics and political dimensions remain important. In large part, the lack of emphasis on 'capital P' actors is one of differences in focus: 
that is, the different choices researchers make when they investigate policymaking processes, which may favour one set of actors over others or specific policy sites over others, or which may simply look at higher or lower levels of abstraction. However, as argued above, changes in the institutional framework of policy advisory systems often do originate with 'capital P' actors, or it is these actors that force changes as they attempt to assert their role. In following the example of John Wanna's body of work, accounting for the role of 'capital P' politics enriches and deepens our understanding of policymaking processes and the evolution of policy advisory systems.

\section{References}

Allen, P. 2013. 'Linking pre-parliamentary political experience and the career trajectories of the 1997 general election cohort'. Parliamentary Affairs 66(4): 685-707. doi.org/10.1093/pa/gss030.

Allen, P. 2014. 'Bring in the professionals: How pre-parliamentary political experience affects political careers in the House of Commons'. PhD thesis. Birkbeck: University of London. Available at: vufind.lib.bbk.ac.uk/vufind/ Record/482473.

Althaus, C., P. Bridgman, and G. Davis. 2007. The Australian Policy Handbook. Crows Nest: Allen \& Unwin.

Bagehot, W. 1963. The English Constitution. London: Collins.

Bateman, J. 2008. In the Shadows: The Shadow Cabinet in Australia. Canberra: The Parliamentary Library.

Bates, S., M. Goodwin and S. McKay. 2017. 'Do UK MPs engage more with Select Committees since the Wright reforms? An interrupted time series analysis, 1979-2016. Parliamentary Affairs 70(4): 780-800. doi.org/ $10.1093 / \mathrm{pa} / \mathrm{gsx} 007$.

Best, H. and M. Cotta (eds). 2000. Parliamentary Representatives in Europe, 1848-2000 : Legislative Recruitment and Careers in Eleven European Countries. Oxford and New York: Oxford University Press.

Cairney, P. 2007. 'The professionalisation of MPs: Refining the "politics-facilitating" explanation'. Parliamentary Affairs 60(2): 212-233. doi.org/10.1093/pa/ gsm006. 
Cairney, P. 2012. Understanding Public Policy: Theories and Issues. Houndmills, Basingstoke, Hampshire and New York: Red Globe Press.

Cohen, M., J. G. March and J. P. Olsen. 1972. 'A garbage can model of organizational choice'. Administrative Science Quarterly 17(1): 1-25. doi.org/ $10.2307 / 2392088$.

Connaughton, B. 2010. “"Glorified gofers, policy experts or good generalists": A classification of the roles of the Irish ministerial adviser'. Irish Political Studies 25(3): 347-369. doi.org/10.1080/07907184.2010.497636.

Connaughton, B. 2015. 'Navigating the borderlines of politics and administration: Reflections on the role of ministerial advisers'. International Journal of Public Administration 38(1): 37-45. doi.org/10.1080/01900692.2014.952820.

Cowley, P. 2012. 'Arise, novice leader! The continuing rise of the career politician in Britain'. Politics 32(1): 31-38. doi.org/10.1111/j.1467-9256.2011.01422.x.

Craft, J. 2015. 'Conceptualizing the policy work of partisan advisers'. Policy Sciences 48(2): 135-158. doi.org/10.1007/s11077-015-9212-2.

Craft, J. 2016. Backrooms and Beyond: Partisan Advisers and the Politics of Policy Work in Canada. University of Toronto Press. doi.org/10.3138/9781442617636.

Craft, J. and J. Halligan. 2017. 'Assessing 30 years of Westminster policy advisory system experience'. Policy Sciences 50(1): 47-62. doi.org/10.1007/s11077-0169256-y.

Dalton, R. J., D. M. Farrell and I. McAllister. 2011. Political Parties and Democratic Linkage: How Parties Organize Democracy. Oxford: Oxford University Press. doi.org/10.1093/acprof:osobl/9780199599356.001.0001.

Diamond, P. 2019. The End of Whitehall? Government by Permanent Campaign. Springer. doi.org/10.1007/978-3-319-96101-9.

Dicey, A. V. 1982. Introduction to the Study of the Law of the Constitution. Reprint of the original 8th edition. Indianapolis: Liberty Classics.

Dowding, K. and P. Dumont (eds). 2015. The Selection of Ministers around the World. London and New York: Routledge. doi.org/10.4324/9781315757865.

Dowding, K. and A. Martin. 2017. Policy Agendas in Australia. Switzerland: Palgrave Macmillan. doi.org/10.1007/978-3-319-40805-7.

Dowding, K. and M. Taflaga. 2020. 'Career de-separation in Westminster democracies'. Political Quarterly 91(1): 116-124. doi.org/10.1111/1467923X.12812. 
Ganghof, S., S. Eppner and A. Pörschke. 2018. 'Australian bicameralism as semiparliamentarism: Patterns of majority formation in 29 democracies'. Australian Journal of Political Science 53(2): 211-233. doi.org/10.1080/10361146.2018. 1451487.

Gauja, A. 2013. The Politics of Party Policy: From Members to Legislators. Houndmills, Basingstoke, Hampshire and New York: Palgrave Macmillan.

Goodwin, M. and S. Bates. 2016. "The "powerless parliament"? Agenda-setting and the role of the UK Parliament in the Human Fertilisation and Embryology Act 2008'. British Politics 11(2): 232-255. doi.org/10.1057/bp.2015.37.

Goodwin, M., S. Bates and S. McKay. 2018. 'Electing to do women's work? Gendered divisions of labour in UK Select Committees, 1979-2016.' In Politics \& Gender. Cambridge: Cambridge University Press. doi.org/ 10.1017/S1743923X19000874.

Goplerud, M. 2015. 'The first time is (mostly) the charm: Special advisers as parliamentary candidates and Members of Parliament'. Parliamentary Affairs 68(2): 332-351. doi.org/10.1093/pa/gst033.

Haddon, C. 2012. Making Policy in Opposition: Lessons for Effective Government. The Institute for Government. Available at: www.instituteforgovernment.org. uk/publications/making-policy-opposition.

Halligan, J. 2008. 'Parliamentary committee roles in facilitating public policy at the Commonwealth level'. Australasian Parliamentary Review 23(2): 135-156.

Halligan, J., R. Miller and J. M. Power. 2007. Parliament in the Twenty-First Century: Institutional Reform and Emerging Roles. Carlton: Melbourne University Press.

Jennings, I. 1966. The British Constitution. 5th edition. Cambridge: Cambridge University Press.

Jones, C. 1970. An Introduction to the Study of Political Life. Berkeley: Duxberry Press.

Kaiser, A. 2008. 'Parliamentary opposition in Westminster democracies: Britain, Canada, Australia and New Zealand'. The Journal of Legislative Studies 14(1): 20-45. doi.org/10.1080/13572330801920887.

Karvonen, L. 2010. The Personalisation of Politics: A Study of Parliamentary Democracies. ECPR Press.

Katz, R. and P. Mair. 2009. 'The cartel party thesis: A restatement'. Perspectives on Politics 7(4): 753-766. doi.org/10.1017/S1537592709991782. 
King, A. 1981. 'The rise of the career politician in the UK'. British Journal of Political Science 11(3): 249-85.

King, A. S. and I. Crewe. 2014. The Blunders of Our Governments. London : Oneworld. Available at: trove.nla.gov.au/version/216213164.

Kingdon, J. 1984. Agendas, Alternatives and Public Policies. New York: Harper Collins.

Kopecký, P., P. Mair, M. Spirova and European Consortium for Political Research. 2012. Party Patronage and Party Government in European Democracies. Oxford : Oxford University Press. doi.org/10.1093/acprof:oso/ 9780199599370.001 .0001 .

Lasswell, H. 1956. The Decision Process: Seven Categories of Functional Analysis. College Park: University of Maryland Press.

Lucy, R. 1993. The Australian Form of Government: Models in Dispute. South Melbourne: Macmillan.

Mair, P. 2007. 'The challenge to party government'. Working Paper. EUI SPS 2007/09. European University Institute. Available at: cadmus.eui.eu// handle/1814/7158.

Maley, M. 2015. 'The policy work of Australian political staff'. International Journal of Public Administration 38(1): 46-55. doi.org/10.1080/01900692. 2014.907311.

Maley, M. 2017. 'Temporary partisans, tagged officers or impartial professionals: Moving between ministerial offices and departments'. Public Administration 95(2): 407-420. doi.org/10.1111/padm.12290.

Maley, M. 2018. 'Parliamentary experience in Australian ministerial careers 1996-2007'. Australian Journal of Politics and History 64(2): 241-259. doi.org/ 10.1111/ajph.12464.

McCaffrie, B. 2012. 'Understanding the success of presidents and prime ministers: The role of opposition parties'. Australian Journal of Political Science 47(2): 257-271. doi.org/10.1080/10361146.2012.677005.

Miragliotta, N. and W. Errington. 2012. 'Legislative recruitment and models of party organisation: Evidence from Australia'. The Journal of Legislative Studies 18(1): 21-40. doi.org/10.1080/13572334.2012.646708.

Norton, P. 2008. 'Making sense of opposition'. The Journal of Legislative Studies 14(1-2): 236-250. doi.org/10.1080/13572330801921257. 
O'Faircheallaigh, C., J. Wanna and P. M. Weller. 1999. Public Sector Management in Australia: New Challenges, New Directions. South Yarra: Macmillan Education Australia.

Pakulski, J. and B. Tranter. 2015. The Decline of Political Leadership in Australia? Changing Recruitment and Careers of Federal Politicians. New York: Palgrave Macmillan.

Peters, B. G., and J. Pierre (eds). 2004. The Politicization of the Civil Service in Comparative Perspective: A Quest for Control. Taylor \& Francis. doi.org/10.4324/ 9780203799857.

Prasser, S. 2010. 'Opposition one day, government the next: Can oppositions make policy and be ready for office?' Australasian Parliamentary Review 25(1): $151-161$.

Prosser, B. and R, Denniss. 2015. Minority Policy: Rethinking Governance When Parliament Matters. Carlton: Melbourne University Press.

Punnett, R. M. 1973. Front-Bench Opposition: The Role of the Leader of the Opposition, the Shadow Cabinet and Shadow Government in British Politics. London: Heinemann Educational Books Ltd.

Rhodes, R. A. W. 1997. Understanding Governance: Policy Networks, Governance, Reflexivity and Accountability. Buckingham: Open University Press.

Rhodes, R. A. W. 2006. 'Policy network analysis'. In M. Moran, M. Rein and R. Goodin (eds) The Oxford Handbook of Public Policy. Oxford: Oxford University Press.

Rhodes, R. A. W. and J. Wanna. 2007. 'The limits to public value, or rescuing responsible government from the platonic guardians'. Australian Journal of Public Administration 66(4): 406-421. doi.org/10.1111/j.1467-8500.2007. 00553.x.

Rhodes, R. A. W. and J. Wanna. 2009. 'Bringing the politics back in: Public value in Westminster parliamentary government'. Public Administration 87(2): 161-183. doi.org/10.1111/j.1467-9299.2009.01763.x.

Rhodes, R. A. W., J. Wanna and P. Weller. 2009. Comparing Westminster. Oxford: Oxford University Press. doi.org/10.1093/acprof:oso/9780199563494.001. 0001 .

Richards, D. and M Smith. 2004. 'The "hybrid state". In S. Ludlam and M. Smith (eds) Governing as New Labor. Basingstoke: Palgrave Macmillan. 
Richardson, J. J. and G. Jordan. 1979. Governing Under Pressure. First edition. Oxford: Blackwell Publishers.

Riddell, P. and C. Haddon. 2009. Transitions: Preparing for Changes of Government. London: Institute for Government. Available at: www.instituteforgovernment. org.uk/publications/transitions.

Taflaga, M. 2016. 'Policy, policy development and political communication during opposition: The Federal Liberal Party of Australia 1983-1996 and 2007-2013'. PhD thesis. Canberra: The Australian National University.

Taflaga, M. and M. Kerby. 2020. 'Who does what work in a ministerial office: Politically appointed staff and the descriptive representation of women in Australian political offices, 1979-2010'. Political Studies 68(2): 463-485. doi.org/10.1177/0032321719853459.

Tiernan, A. and P. Weller. 2010. Learning to Be a Minister: Heroic Expectations, Practical Realities. Carlton: Melbourne University Press.

Uhr, J. 2009. 'Parliamentary oppositional leadership'. In P. 't Hart, J. Kane and H. Patapan (eds) Dispersed Democratic Leadership: Origins, Dynamics, and Implications. New York: Oxford University Press. doi.org/10.1093/acprof:oso/ 9780199562992.003.0004.

Uhr, J. and J. Wanna. 2000. 'The future roles of parliament'. In J. Wanna, P. Weller and M. Keating (eds) Institutions on the Edge? Capacity for Governance. St Leonards: Allen \& Unwin.

Wanna, J. 1993. 'Political parties and the policy process'. In S. Prasser and A. Hede (eds) Policy-Making in Volatile Times. Sydney: Hale \& Iremonger.

Wanna, J. and P. Weller. 2003. 'Traditions of Australian governance'. Public Administration 81(1): 63-94. doi.org/10.1111/1467-9299.00337.

Wilson, R. P. 2015. 'Research note: A profile of ministerial policy staff in the Government of Canada'. Canadian Journal of Political Science/Revue Canadienne de Science Politique 48(2): 455-471. doi.org/10.1017/S0008 423915000293. 
This text is taken from Politics, Policy and Public Administration in Theory and Practice: Essays in Honour of Professor John Wanna, edited by Andrew Podger, Michael de Percy and Sam Vincent, published 2021 by ANU Press, The Australian National University, Canberra, Australia.

doi.org/10.22459/PPPATP.2021.08 